\title{
KETERKAITAN SELF ASSESSMENT SYSTEM, KUALITAS PELAYANAN DAN PEMERIKSAAN PAJAK TERHADAP KEPATUHAN WAJIB PAJAK ORANG PRIBADI
}

\author{
Narti Eka Putri ${ }^{1}$ dan Apriliyah Pharamitha ${ }^{2}$ \\ UNIVERSITAS TANRI ABENG \\ 1Narti.putri@tau.ac.id
}

\begin{abstract}
Abstrak - Penerimaan pajak memiliki kontribusi yang sangat besar dalam APBN, sehingga pemerintah harus berupaya untuk selalu meningkatkan dan mempertahankan penerimaan pajak. Usaha untuk memaksimalkan penerimaan pajak tidak hanya mengandalkan peran dari Ditjen pajak ataupun pihak fiskus, namun dibutuhkan juga peran aktif dari wajib pajak itu sendiri. Pada kenyataannya, kepatuhan wajib pajak bukanlah hal yang mudah untuk direalisasikan. Penelitian ini bertujuan untuk mengetahui pengaruh pelaksanaan self assessment system, kualitas pelayanan dan pemeriksaan pajak terhadap kepatuhan wajib pajak orang pribadi. Metode penelitian yang digunakan adalah penelitian kuantitatif dengan pengumpulan data primer berupa survey langsung dengan cara memberikan kuesioner kepada wajib pajak orang pribadi di KPP Pratama Kebayoran Baru Tiga. Dengan menggunakan rumus Slovin, sampel yang diambil sebanyak 391 responden. Setelah diolah dengan aplikasi SPSS versi 24, didapatlah hasil bahwa self assessment system, kualitas pelayanan dan pemeriksaan pajak berpengaruh signifikan secara parsial terhadap kepatuhan wajib pajak orang pribadi.
\end{abstract}

Keywords - Self Assessment System, Kualitas Pelayanan, Pemeriksaan Pajak, Kepatuhan Wajib Pajak

\section{PENDAHULUAN}

\subsection{Latar Belakang Masalah}

Salah satu fungsi pajak adalah fungsi penerimaan (budgetair). Pajak berfungsi sebagai sumber dana yang digunakan untuk membiayai pengeluaranpengeluaran pemerintah (Waluyo, 2008). Sumber pendapatan APBN terbesar diperoleh dari sektor pajak. Berikut disajikan penerimaan pajak dari tahun 2014 sampai dengan 2018. 
Tabel 1. Penerimaan Pajak Di APBN

\begin{tabular}{ccccc} 
No. & Tahun anggaran & $\begin{array}{c}\text { Pendapatan di } \\
\text { APBN (triliun) }\end{array}$ & $\begin{array}{c}\text { Penerimaan } \\
\text { Pajak(triliun) }\end{array}$ & $\begin{array}{c}\text { Persentase } \\
\text { pajak }\end{array}$ \\
\hline 1. & 2018 & 1.895 & 1.618 & $85 \%$ \\
2. & 2017 & 1.750 & 1.499 & $85 \%$ \\
3. & 2016 & $1.822,5$ & $1.360,2$ & $75 \%$ \\
4. & 2015 & $1.761,6$ & 1294,3 & $73 \%$ \\
5. & 2014 & $1.550,6$ & 985,1 & $64 \%$ \\
\multicolumn{4}{r}{ Sumber: $w$ ww.depkeu.go.id, diolah, 2018}
\end{tabular}

Dari tabel diatas, menunjukkan bahwa penerimaan pajak memiliki kontribusi yang sangat besar dalam APBN, sehingga pemerintah harus berupaya untuk selalu meningkatkan dan mempertahankan penerimaan pajak. Usaha untuk memaksimalkan penerimaan pajak tidak hanya mengandalkan peran dari Ditjen pajak ataupun pihak fiskus, namun dibutuhkan juga peran aktif dari wajib pajak itu sendiri.

Pada kenyataannya, kepatuhan wajib pajak bukanlah hal yang mudah untuk direalisasikan. Berikut ini merupakan Tabel Pengolahan Data Wajib Pajak Orang Pribadi yang dapat memperlihatkan kepatuhan wajib pajak dalam melaksanakan kewajiban perpajakannya.

Tabel 2. Tingkat Kepatuhan WPOP di KPP Kebayoran Baru Tiga

\begin{tabular}{lllll}
$\begin{array}{l}\text { Tahun } \\
\text { pajak }\end{array}$ & $\begin{array}{l}\text { WPOP nonawan } \\
\text { karyan }\end{array}$ & $\begin{array}{l}\text { WPOP } \\
\text { karyawan }\end{array}$ & $\begin{array}{l}\text { WP } \\
\text { melaporkan } \\
\text { SPT }\end{array}$ & $\begin{array}{l}\text { Persentase } \\
\text { kepatuhan }\end{array}$ \\
\hline 2017 & 3.997 & 12.783 & 5.705 & $34 \%$ \\
2016 & 3.860 & 12.051 & 5.804 & $36 \%$ \\
2015 & 3.848 & 11.610 & 4.996 & $32 \%$ \\
& & & \multicolumn{2}{c}{ Sumber: KPP Pratama Kebayoran Baru Tiga }
\end{tabular}

Berdasarkan tabel diatas, dapat dilihat bahwa dari tahun 2015 hingga tahun 2017 jumlah wajib pajak Orang Pribadi yang terdaftar di KPP Pratama Kebayoran Baru Tiga senantiasa bertambah, baik dari wajib pajak orang pribadi karyawan maupun non karyawan. Namun jika dilihat dari persentasi tingkat kepatuhan antara tahun 2015 ke tahun 2016 mengalami kenaikan, namun pada tahun 2017 mengalami penurunan. Persentasi tingkat kepatuhan juga masih di bawah 50\% sehingga masih tergolong sangat rendah. Hal tersebut dikarenakan banyaknya wajb pajak yang tidak melaporkan SPT tahunannya, sehingga menyebabkan tingkat kepatuhannya rendah. Oleh sebab itu, perlu dilakukan suatu kajian guna mengetahui faktor-faktor apa yang mempengaruhi tingkat kepatuhan wajib pajak di Kebayoran Baru. 
Persoalan utama yang saat ini dihadapi Direktorat Jenderal Pajak Kementerian Keuangan adalah rendahnya kepatuhan masyarakat terhadap perpajakan, ketika sistem pemungutan pajak beralih dari official assessment (proses penghitungan dilakukan oleh Ditjen Pajak) menjadi self assessment (proses penghitungan dilakukan sendiri oleh wajib pajak), maka ada beberapa persyaratan yang harus dipenuhi terlebih dahulu, syarat tersebut adalah adanya tingkat pengetahuan pajak yang cukup baik di masyarakat dan tingkat kejujuran yang tinggi dalam mengisi serta melaporkan surat pemberitahuan (SPT) pajak, namun sayangnya dua persyaratan tersebut belum terpenuhi secara maksimal dan pelaksanaan sistem self assessment tidak optimal, sehingga dampaknya tingkat kepatuhan perpajakan masih rendah (Chandra Budi, 2014).

Self assessment system merupakan sistem pemungutan pajak yang memberi wewenang, kepercayaan, tanggung jawab kepada wajib pajak untuk menghitung, memperhitungkan, membayar, dan melaporkan sendiri besarnya pajak yang harus dibayar (Waluyo, 2008). Berdasarkan penelitian terdahulu yang dilakukan oleh S. Mia Lasmaya dan Neni Nur Fitriani (2017) menyatakan bahwa self assessment system berpengaruh terhadap kepatuhan wajib pajak orang pribadi pada salah satu KPP Pratama di Kota Bandung. Dwi Agus Setyono (2017) menemukan bahwa self assessment system berpengaruh signifikan positif terhadap kepatuhan wajib pajak di KPP Pratama Jember. Namun penelitian ini tidak sejalan dengan yang dilakukan oleh Inggrid Grace Manuputty dan Swanto Sirait (2016) menyatakan bahwa self assessment system secara parsial tidak berpengaruh signifikan terhadap kepatuhan wajib pajak.

Salah satu upaya untuk meningkatkan penerimaan pajak adalah memberikan pelayanan yang baik kepada Wajib Pajak. Pelayanan yang diberikan kepada Wajib Pajak merupakan pelayanan publik yang lebih diarahkan sebagai suatu cara pemenuhan kebutuhan masyarakat dalam rangka pelaksanaan peraturan perundang-undangan yang berlaku. Pelayanan pada Wajib Pajak bertujuan untuk menjaga kepuasan wajib pajak yang nantinya diharapkan dapat meningkatkan kepatuhan wajib pajak dalam memenuhi kewajiban perpajakannya. Jika pelayanan terhadap wajib pajak baik maka akan berdampak kepada penerimaan pajak untuk tahun-tahun berikutnya (Sri Putri, 2013).

Hasil penelitian terdahulu yang dilakukan oleh Farid Syahril (2013) menyatakan bahwa kualitas pelayanan fiskus berpengaruh signifikan positif terhadap tingkat kepatuhan wajib pajak. Penelitian serupa juga dilakukan oleh Nunung Nurhayati, dkk (2015) menyatakan bahwa kualitas pelayanan berpengaruh signifikan terhadap kepatuhan wajib pajak. Namun, penelitian ini tidak sejalan dengan yang dilakukan oleh Kilapong G. Ester, dkk (2017) menyatakan bahwa kualitas pelayanan pajak tidak berpengaruh signifikan terhadap kepatuhan wajib pajak pribadi.

Untuk meningkatkan kepatuhan wajib pajak, pemeriksaan juga penting untuk dilakukan. Menurut Andyastuti, dkk (2013) tujuan utama pemeriksaan 
adalah untuk meningkatkan pemenuhan pajak. Pemeriksaan pajak berguna sebagai pengawas atau pengontrol agar pelaksanaan perpajakan dapat dilaksanakan sesuai peraturan perpajakan. Penelitian terdahulu yang dilakukan oleh Putu Aditya Wira Artawan, dkk (2017) menyatakan bahwa pemeriksaan secara individu berpengaruh positif dan signifikan terhadap kepatuhan Wajib Pajak Orang Pribadi pada KPP Singaraja. Hasil penelitian serupa juga dilakukan oleh Kusujarwati Anjarini Buntoro, dkk (2012) menyatakan bahwa pemeriksaan pajak berdampak positif terhadap kepatuhan wajib pajak orang pribadi pada KPP Pratama Sawah Besar Satu. Namun penelitian ini tidak sejalan dengan Cynthia Pradisti Amanda, dkk (2014) menyatakan bahwa pemeriksaan pajak tidak berpengaruh signifikan terhadap kepatuhan wajib pajak.

Perbedaan hasil penelitian diatas membuat peneliti tertarik untuk kembali meneliti tentang kepatuhan wajib pajak. Berdasarkan uraian pada latar belakang diatas, maka permasalahan dalam penelitian ini adalah sebagai berikut:

1.Apakah pelaksanaan self assessment system berpengaruh terhadap kepatuhan wajib pajak orang pribadi di KPPKebayoran Baru Tiga?

2. Apakah kualitas pelayanan berpengaruh terhadap kepatuhan wajib pajak orang pribadi di KPPKebayoran Baru Tiga ?

3. Apakah pemeriksaan pajak berpengaruh terhadap kepatuhan wajib pajak orang pribadi di KPPKebayoran Baru Tiga ?

\section{KAJIAN LITERATUR}

Menurut Undang-undang Nomor 16 tahun 2009 tentang perubahan keempat atas Undang-undang Nomor 6 tahun 1983 tentang Ketentuan Umum dan Tata Cara Perpajakan pada pasal 1 ayat 1 berbunyi pajak adalah kontribusi wajib kepada negara yang terutamg oleh pribadi atau badan yang bersifat memaksa berdasarkan Undang-undang, dengan tidak mendapatkan imbalan secara langsung dan digunakan untuk keperluan Negara bagi sebesar-besarnya kemakmuran rakyat (Mardiasmo, 2016).

Terdapat dua fungsi pajak dalam menjalankan pemerintahanmenurut Mardiasmo (2016:4) yaitu:

1. Fungsi anggaran (Budgetair)

Pajak berfungsi sebagai salah satu sumber dana bagi pemerintah untuk membiayai pengeluaran-pengeluarannya.

2. Fungsi mengatur (Regulerend)

Pajak berfungsi sebagai alat untuk mengatur atau melaksanakan kebijaksanaan pemerintah dalam bidang sosisal dan ekonomi.

Menurut Waluyo (2013:17) sistem pemungutan pajak dibagi menjadi 3 (tiga) yaitu: 


\section{Sistem Official Assessment}

Sistem ini merupakan sistem pemungutan pajak yang memberi wewenang kepada pemerintah (fiskus) untuk menentukan besarnya pajak yang terutang.

\section{Sistem Self Assessment}

Sistem ini merupakan pemungutan pajak yang memberi wewenang, kepercayaan, tanggung jawab kepada Wajib Pajak untuk menghitung, memperhitungkan, membayar dan melaporkan sendiri besarnya pajak yang harus dibayar.

\section{Sistem Witholding}

Sistem ini merupakan sistem pemungutan pajak yang memberi wewenang kepada pihak ketiga untuk memotong atau memungut besarnya pajak yang terutang oleh Wajib Pajak.

Ciri-ciri self assessment system menurut Siti Kurnia Rahayu (2017:112) adalah:

1. Wajib Pajak (dapat dibantu oleh Konsultan Pajak) melakukan peran aktif dalam melaksanakan kewajiban perpajaknnya.

2. Wajib Pajak adalah pihak yang bertanggung jawab penuh atas kewajiban perpajakannya sendiri.

3. Pemerintah dalam hal ini Instansi Perpajakan melakukan pembinaan, penelitian, dan pengawasan terhadap pelaksanaan kewajiban perpajakan bagi Wajib Pajak, melalui pemeriksaan pajak dan penerapan sanksi pelanggaran dalam bidang pajak sesuai peraturan yang berlaku.

Menurut Erly Suandy (2011:128) untuk menyukseskan pelaksanaan sistem pemungutan self assessment ini dibutuhkan beberapa prasyarat dari Wajib Pajak sebagai berikut.

\section{Kesadaran Wajib Pajak (Tax Consciousness)}

Kesadaran Wajib Pajak artinya Wajib Pajak mau dengan sendirinya melakukan kewajiban perpajakannya seperti mendaftarkan diri, menghitung, membayar dan melaporkan jumlah pajak terutangnya. 


\section{Kejujuran Wajib Pajak}

Kejujuran Wajib Pajak artinya Wajib Pajak melakukan kewajibannya dengan sebenar-benarnya tanpa adanya manipulasi, hal ini dibutuhkan didalam sistem ini karena fiskus memberi kepercayaan kepada Wajib Pajak untuk mendaftarkan diri, menghitung, membayar, dan melaporkan sendiri jumlah pajak yang terutangnya.

3. Kemauan Membayar Pajak dari Wajib Pajak (Tax Mindedness)artinya Wajib Pajak selain memiliki kesadaran akan kewajiban perpajakannya, namun juga dalam dirinya memiliki hasrat dan keinginan yang tinggi dalam membayar pajak terutangnya.

\section{Kedislipinan Wajib Pajak (Tax Disciplin)}

Kedisiplinan Wajib Pajak artinya Wajib Pajak dalam melakukan kewajiban perpajakannya dilakukan dengan tepat waktu sesuai dengan ketentuan dan peraturan yang berlaku.

Berdasarkan Peraturan Direktur Jenderal Pajak Nomor PER-02/PJ/2014 pasal 1 ayat 2 pelayanan perpajakan adalah pelayanan yang diberikan oleh unit kerja di lingkungan Direktorat Jenderal Pajak kepada masyarakat sesuai dengan ketentuan perpajakan yang berlaku.

Menurut Parasuraman et al. (1998) dalam Tjiptono (2016:137) mengemukakan bahwa terdapat lima dimensi yang digunakan untuk menilai kualitas pelayanan, yaitu :

1. Reabilitas (Reliability), berkaitan dengan kemampuan perusahaan untuk memberikan layanan yang akurat sejak pertama kali tanpa membuat kesalahan apapun dan menyampaikan jasanya sesuai dengan waktu yang disepakati.

2.Daya Tanggap (Responsiveness), berkenaan dengan kesediaan dan kemampuan para karyawan untuk membantu para pelanggan dan merespon permintaan mereka, serta menginformasikan kapan jasa akan diberikan dan kemudian memberikan jasa secara cepat.

3.Jaminan (Assurance), yakni perilaku karyawan mampu menumbuhkan kepercayaan pelanggan terhadap perusahaan dan perusahaan bias menciptakan rasa aman bagi para pelanggannya. Jaminan juga berarti bahwa para karyawan selalu bersikap sopan dan menguasai pengetahuan dan keterampilan yang dibutuhkan untuk menangani setiap pertanyaan atau masalah pelanggan.

4.Empati (Emphaty), berarti bahwa perusahaan memahami masalah para pelanggannya dan bertindak demi kepentingan pelanggan, serta 
memberikan perhatian personal kepada para pelanggan dan memiliki jam operasi yang nyaman.

5.Bukti fisik (Tangibles), berkenaan dengan daya tarik fasilitas fisik, perlengkapan, dan material yang digunakan perusahaan, serta penampilan karyawan.

Berdasarkan Peraturan Direktur Jenderal Pajak Nomor PER176/PJ./2006pemeriksaan adalah serangkaian kegiatan untuk mencari, mengumpulkan, mengolah data dan atau keterangan lainnya untuk menguji kepatuhan pemenuhan kewajiban perpajakan dan untuk tujuan lain dalam rangka melaksanakan ketentuan peraturan perundang-undangan perpajakan”.

Tujuan pemeriksaan dan kewenangan pihak yang melakukan pemeriksaan sebagaimana dimuat dalam Pasal 29 ayat (1) Undang-Undang Ketentuan Umum dan Tata Cara Perpajakan menyatakan, "Direktur Jenderal Pajak berwenang melakukan pemeriksaan untuk menguji kepatuhan pemenuhan kewajiban perpajakan Wajib Pajak dan untuk tujuan lain dalam rangka melaksanakan ketentuan peraturan perundang-undangan perpajakan" Waluyo (2013:67).

Menurut Mardiasmo (2016:57) yang menjadi sasaran pemeriksaan maupun penyelidikan adalah untuk mencari adanya :

a) Interprestasi Undang-undang yang tidak benar

b) Kesalahan hitung

c) Penggelapan secara khusus dari penghasilan

d) Pemotongan dan pengurangan tidak sesungguhnya, yang dilakukan Wajib Pajak dalam melaksanakan kewajiban perpajakannya.

Menurut Chaizi Nasucha dalam Siti Kurnia Rahayu (2010:139) kepatuhan wajib pajak dapat diidentifikasi dari:

a. Kepatuhan wajib pajak dalam mendaftarkan diri

b. Kepatuhan untuk melaporkan kembali surat pemberitahuan

c. Kepatuhan dalam penghitungan dan pembayaran pajak terutang

d. Kepatuhan dalam pembayaran tunggakan

Menurut Peraturan Menteri Keuangan Republik Indonesia Nomor 74/PMK.03/2012 kriteria wajib pajak patuh adalah:

1.Tepat waktu dalam menyampaikan Surat Pemberitahuan; 
2. Tidak mempunyai tunggakan pajak untuk semua jenis pajak, kecuali tunggakan pajak yang telah memperoleh izin mengangsur atau menunda pembayaran pajak;

3.Laporan Keuangan diaudit oleh Akuntan Publik atau lembaga pengawasan keuangan pemerintah dengan pendapat Wajar Tanpa Pengecualian selama 3 (tiga) tahun berturut-turut; dan

4. Tidak pernah dipidana karena melakukan tindak pidana di bidang perpajakan berdasarkan putusan pengadilan yang telah mempunyai kekuatan hukum tetap dalam jangka waktu 5 (lima) tahun terakhir.

Sedangkan tepat waktu dalam penyampaian Surat Pemberitahuan yaitu:

1.Penyampaian Surat Pemberitahuan Tahunan selama 3 (tiga) Tahun Pajak terakhir yang wajib disampaikan sampai dengan akhir tahun sebelum tahun penetapan Wajib Pajak dengan kriteria tertentu dilakukan tepat waktu;

2.Penyampaian Surat Pemberitahuan Masa yang terlambat dalam tahun terakhir sebelum tahun penetapan Wajib Pajak Dengan Kriteria Tertentu untuk Masa Pajak Januari sampai November tidak lebih dari 3 (tiga) Masa Pajak untuk setiap jenis pajak dan tidak berturut-turut;

3. Seluruh Surat Pemberitahuan Masa dalam tahun terakhir sebelum tahun penetapan Wajib Pajak Dengan Kriteria Tertentu untuk Masa Pajak Januari sampai November telah disampaikan; dan

4. Surat Pemberitahuan Masa yang terlambat sebagaimana dimaksud pada nomor dua telah disampaikan tidak lewat dari batas waktu penyampaian Surat Pemberitahuan Masa Masa Pajak berikutnya.

\subsection{Pengembangan Hipotesis}

Self assessment system berperan serta masyarakat sebagai wajib pajak dituntut didalam pemenuhan kewajiban perpajakan penting dalam keberhasilan pengumpulan pajak. Jika sistem tersebut dilaksanakan dengan baik maka dapat meningkatkan kepatuhan sukarela secara otomatis. Dan apabila semakin banyak wajib pajak yang melakukan penerapan self assessment system dengan baik maka akan semakin meningkat pula kepatuhan wajib pajak (S Mia, 2017).

Berdasarkan hasil penelitian S. Mia Lasmaya dan Neni Nur Fitriani (2017) menunjukkan bahwa adanya pengaruh positif antara self assessment system terhadap kepatuhan wajib pajak orang pribadi. Menurut Dwi Agus Setyono (2017) mengemukakan bahwa self assessment system berpengaruh signifikan positif terhadap kepatuhan wajib pajak. Menurut Gede Anton Mardiana, dkk (2016) mengemukakan bahwa self assessment system berpengaruh signifikan terhadap kepatuhan wajib pajak. Penelitian ini juga 
sejalan dengan Dadan Sumpena (2014) yang menyatakan bahwa self assessment system berpengaruh positif dan signifikan terhadap kepatuhan wajib pajak di Kantor Pelayanan Pajak Pratama Bandung Karees. Berdasarkan uraian tersebut dapat dikatakan bahwa self assessment diduga akan berpengaruh terhadap kepatuhan wajib pajak dalam membayar pajak. Oleh karena itu maka dirumuskan hipotesis sebagai berikut:

\section{$H 1$ : Pelaksanaan self assessment system berpengaruh terhadap kepatuhan wajib pajak orang pribadi.}

Hasil penelitian yang dilakukan Nunung Nurhayati, dkk (2015) dan Cynthia Pradisti Amanda, dkk (2014) menyatakan bahwa pelayanan fiskus berpengaruh signifikan terhadap kepatuhan wajib pajak. Penelitian ini juga sejalan dengan Cindy Jotopurnomo dan Yenni Mangoting (2013) yang menyatakan bahwa kualitas pelayanan fiskus berpengaruh signifikan terhadap kepatuhan Wajib Pajak Orang Pribadi di Surabaya. Berdasarkan uraian tersebut dapat dikatakan bahwa kualitas pelayanan diduga akan berpengaruh terhadap kepatuhan wajib pajak dalam membayar pajak. Oleh karena itu maka dirumuskan hipotesis sebagai berikut:

H2 : Kualitas pelayanan berpengaruh terhadap kepatuhan wajib pajak orang pribadi.

Menurut Isa dan Pope (2010) pemeriksaan merupakan karakteristik kunci dari mekanisme kepatuhan sukarela dalam sistem self assessment karena dengan semakin tinggi tingkat pemeriksaan akan dapat meningkatkan kepatuhan pajak. Penelitian yang dilakukan oleh Putu Aditya Wira Artawan, dkk (2017) menyatakan bahwa pemeriksaan secara individu berpengaruh positif dan signifikan terhadap kepatuhan Wajib Pajak Orang Pribadi. Hasil penelitian serupa juga dilakukan oleh Mentari Rahayu Putri (2016) yang menyatakan bahwa pemeriksaan pajak berpengaruh terhadap kepatuhan wajib pajak orang pribadi dalam menyampaikan SPT tahunan. Kusujarwati Anjarini, dkk (2012) mengemukakan bahwa pemeriksaan pajak berdampak positif terhadap kepatuhan Wajib Pajak Orang Pribadi pada KPP Pratama Sawah Besar Satu. Berdasarkan uraian tersebut dapat dikatakan bahwa kualitas pemeriksaan pajak diduga akan berpengaruh terhadap kepatuhan wajib pajak. Oleh karena itu maka dirumuskan hipotesis sebagai berikut:

H3 : Pemeriksaan pajak berpengaruh terhadap kepatuhan wajib pajak 


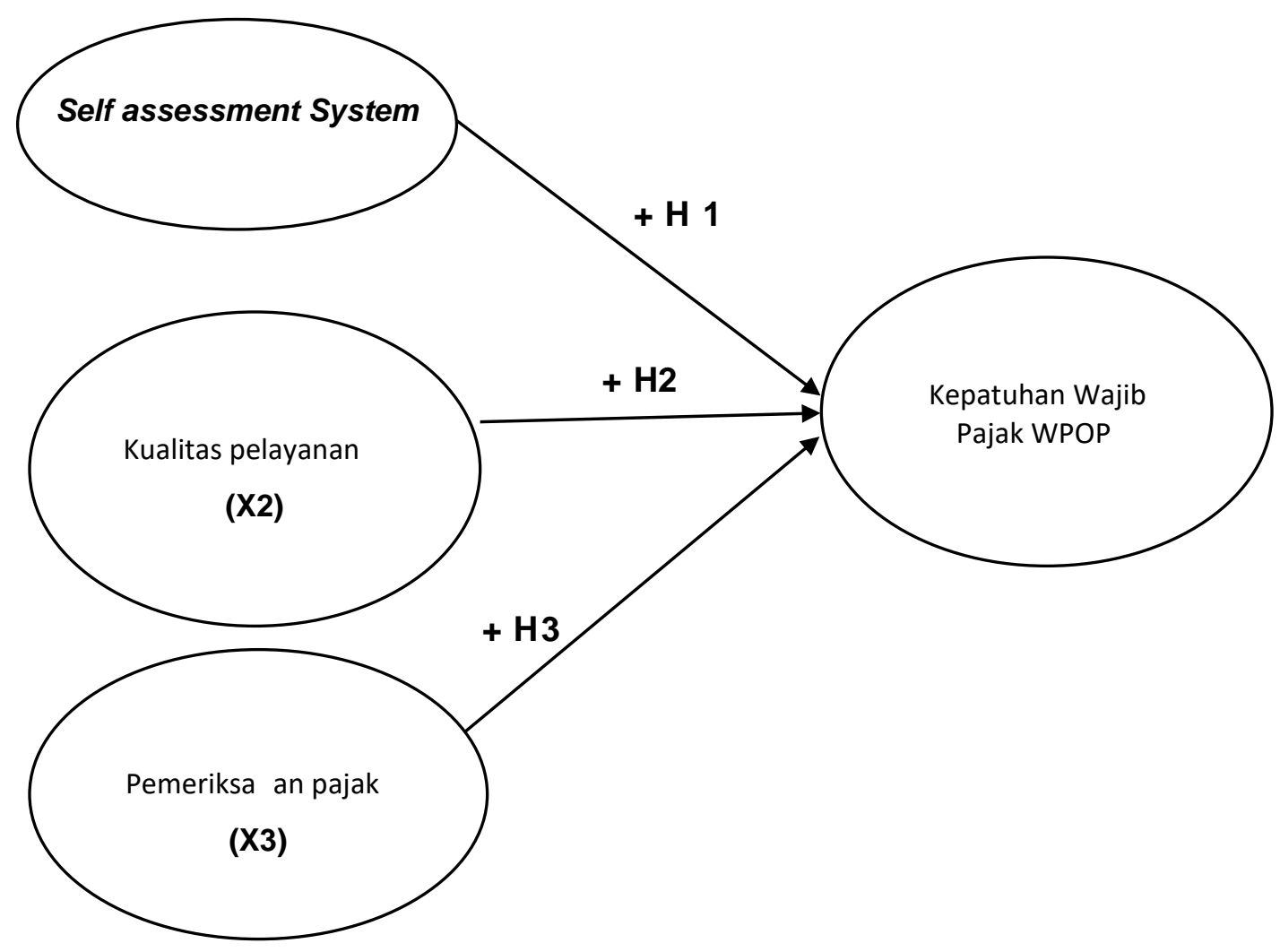

Gambar 1. Kerangka Pemikiran Teoritis

\section{METODE PENELITIAN}

Penelitian ini menggunakan pendekatan kuantitatif yang menekankan pada pengujian teori-teori melalui pengukuran variabel-variabel penelitian dengan angka dan melakukan analisis data dengan prosedur statistik. Model yang dibangun dalam penelitian ini melibatkan tiga variabel bebas yang diidentifikasi mempengaruhi kepatuhan Wajib Pajak Badan di KPP Pratama Kebayoran Baru Tiga yaitu pelaksanaa self assessment, kualitas pelayanan dan pemeriksaan pajak. Peneliti menggunakan analisis statistik deskriptif

Populasi dalam penelitian ini adalah seluruh Wajib Pajak Orang Pribadi yang terdaftar di KPP Pratama Kebayoran Baru Tiga di tahun 2017sebanyak 16.780 WPOP. Penentuan sampel ditentukan dengan rumus slovin:

$$
\begin{aligned}
& \mathrm{n}=\frac{\mathrm{N}}{1+\mathrm{N}(\text { moe })^{2}} \\
& =\quad 390,68 \approx \text { dibulatkan menjadi } 391
\end{aligned}
$$

Keterangan:

$\mathrm{n}=$ Jumlah sampel

$\mathrm{N}=$ Jumlah populasi 
moe : Margin of error maximum, yaitu tingkat kesalahan maksimum yang masih dapat ditoleransi (ditentukan 5\%)

Teknik pengambilan sampel yang digunakan dalam penelitian ini adalah simple random.Denganmenggunakan data primer dan sekunder, penulis mengumpulkan data primer dengan cara survei langsung memberikan kuesioner pada responden wajib pajak orang pribadi yang terdaftar di KPP Kebayoran Baru Tiga. Sedangkan untuk data sekunder penulis mengadakan tinjauan kepustakaan (library research), mengakses website dan situs-situs sehubungan dengan masalah yang diteliti guna memperoleh landasan teoritis yang memadai untuk melakukan pembahasan.

Definisi operasional variabel dari pelaksanaan self assessment system, kualitas pelayanan fiskus, dan pemeriksaan pajak terhadap kepatuhan wajib pajak yaitu secara ringkas disajikan pada tabel 3 sebagai berikut.

Tabel. 3 Instrumen Variabel

\begin{tabular}{|c|c|c|c|c|}
\hline & Variabel & Definisi & Indikator & Pengukuran \\
\hline \multirow[t]{4}{*}{1.} & \multirow[t]{4}{*}{$\begin{array}{l}\text { Kepatuhan } \text { Wajib } \\
\text { Pajak (Y) }\end{array}$} & \multirow{4}{*}{ 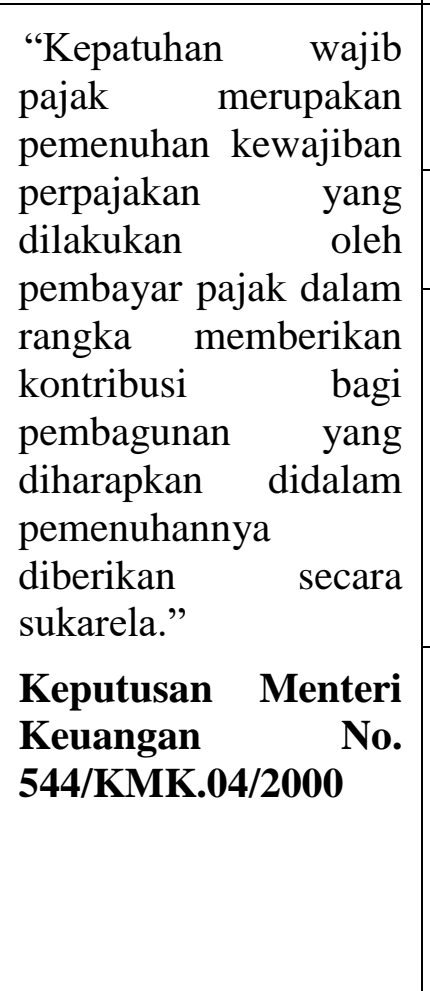 } & $\begin{array}{l}\text { Tepat waktu dalam } \\
\text { menyampaikan Surat } \\
\text { Pemberitahuan }\end{array}$ & \multirow{4}{*}{$\begin{array}{l}5 \text { poin Skala } \\
\text { Likert, } 1 \\
\text { untuk Sangat } \\
\text { Tidak Setuju } \\
\text { (STS) hingga } \\
5 \text { untuk } \\
\text { Sangat Setuju } \\
\text { (SS) }\end{array}$} \\
\hline & & & $\begin{array}{l}\text { Tidak mempunyai } \\
\text { tunggakan pajak }\end{array}$ & \\
\hline & & & $\begin{array}{lr}\text { Tidak } & \text { pernah } \\
\text { dipidana } & \text { karena } \\
\text { melakukan } & \text { tindak } \\
\text { pidana di } & \text { bidang } \\
\text { perpajakan } & \text { dalam } \\
\text { jangka waktu } 5 & \text { (lima) } \\
\text { tahun terakhir. }\end{array}$ & \\
\hline & & & $\begin{array}{ll}\text { Penyampaian } & \text { Surat } \\
\text { Pemberitahuan } & \\
\text { Tahunan selama } 3 \\
\text { (tiga) Tahun } & \text { Pajak } \\
\text { terakhir yang } & \text { wajib } \\
\text { disampaikan } & \text { tepat } \\
\text { waktu } & \end{array}$ & \\
\hline \multirow[t]{2}{*}{2.} & \multirow[t]{2}{*}{$\begin{array}{ll}\text { Self } & \text { Assessment } \\
(\mathrm{X} 1) & \end{array}$} & \multirow{2}{*}{$\begin{array}{l}\text { "Suatu sistem } \\
\text { pemungutan pajak } \\
\text { dimana wajib pajak } \\
\text { harus menghitung, } \\
\text { memperhitungkan, } \\
\text { membayar, dan }\end{array}$} & $\begin{array}{l}\text { Mendaftarkan diri ke } \\
\text { Kantor Pelayanan } \\
\text { Pajak Pratama sesuai } \\
\text { wilayahnya }\end{array}$ & \multirow{2}{*}{$\begin{array}{lr}5 \text { poin } & \text { Skala } \\
\text { Likert, } & 1 \\
\text { untuk } & \text { Sangat } \\
\text { Tidak } & \text { Setuju } \\
(\text { STS }) & \text { hingga } \\
5 & \text { untuk }\end{array}$} \\
\hline & & & $\begin{array}{l}\text { Menghitung pajak } \\
\text { terutang }\end{array}$ & \\
\hline
\end{tabular}




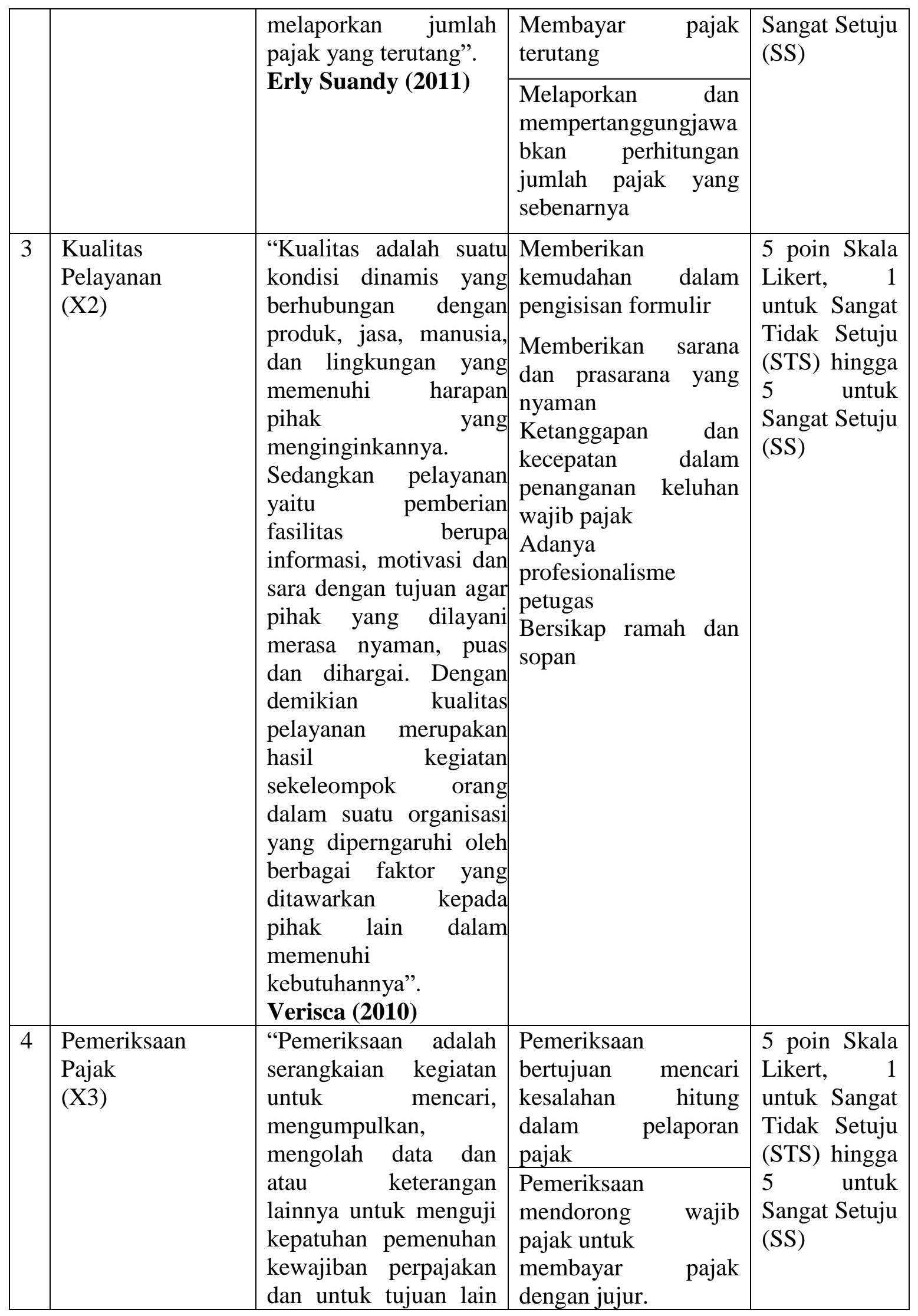




\begin{tabular}{|c|c|c|c|}
\hline & \multirow{2}{*}{\begin{tabular}{|l} 
dalam rangka \\
melaksanakan \\
ketentuan peraturan \\
perundang-undangan \\
perpajakan". \\
Peraturan Direktur \\
Jenderal Pajak \\
Nomor PER \\
123/PJ/2006
\end{tabular}} & $\begin{array}{l}\text { Menguji kepatuhan } \\
\text { pemenuhan kewajiban } \\
\text { perpajakan }\end{array}$ \\
\hline & & & $\begin{array}{l}\text { Melaksanakan } \\
\text { ketentuan peraturan } \\
\text { perundang-undangan } \\
\text { perpajakan }\end{array}$ \\
\hline
\end{tabular}

Sumber : Penelitian terdahulu, diolah.

Keterangan : * Angka dalam Notasi Variabel tidak menunjukkan peringkat

Dalam penelitian ini, untuk uji reliabilitas menggunakan cara one shot atau pengukuran sekali saja; dimana pengukuran hanya dilakukan sekali dan kemudian hasilnya dibandingkan dengan pertanyaan lain atau mengukur antara korelasi antar jawaban pertannyaan yang dibuat (Ghozali, 2016). Disini peneliti menggunakan SPSS untuk mengukur reabilitas dengan uji statistik Cronbach Alpha $(\alpha)$. Suatu variabel tersebut dikatakan reliabel jika memiliki nilai Cronbach Alpha > 0.7 (Ghozali, 2016).

Uji validitas digunakan untuk mengukur sah atau valid tidaknya suatu kuesioner tersebut. Suatu kuesioner tersebut dikatakan valid jika pertanyaan yang terdapat pada kuesioner tersebut mampu untuk mengungkapkan sesuatu yang akan diukur oleh kuesioner tersebut. Untuk mengetahui validitas dari kuesioner yang dibuat oleh peneliti, peneliti menggunakan cara melakukan korelasi antar skor butir pertanyaan dengan total skor variabel. Jika $r$ hitung lebih besar dari $r$ tabel dan bernilai positif maka indikator tersebut valid (Ghozali, 2016). Bila harga korelasi dibawah 0,30, maka dapat disimpulkan kalau pertanyaan dalam kuesioner tersebut tidak valid, sehingga harus diperbaiki atau dibuang.

Uji normalitas bertujuan untuk menguji ada tidaknya variabel pengganggu yang mempunyai distribusi normal dalam model regresi (Ghozali, 2016). Model regresi yang baik adalah yang berdistribusi normal atau mendekati normal. Seperti yang telah di ketahui bahwa uji t dan uji $\mathrm{F}$ mengasumsikan bahwa nilai residual mengikuti distribusi normal. Alat uji normalitas yang digunakan untuk menguji data yang berdistribusinormal adalah One Sample Kolmogorov-Smirnov (KS). Pada pengujian normalitas dengan menggunakan uji Kolmogorov-Smirnov, jika probability value $>0,05$ maka Ho diterima (berdistribusi normal) sedangkan jika probability value $<0,05$ maka Ho ditolak (tidak berdistribusi normal).

Uji multikolinieritas digunnakan untuk menguji apakah dalam model regresi ditemukan adanya korelasi antar variabel independen (Ghozali, 2016). Multikolonieritas dapat dilihat dari nilai tolerance dan variance inflation factor (VIF). Tolerance mengukur variabilitas variabel independen yang terpilih yang tidak dijelaskan oleh variabel independen lainnya. Jadi, nilai Tolerance yang rendah sama dengan nilai VIF tinggi (karena VIF $=1 /$ Tolerance). Nilai cutoff yang umum dipakai untuk menunjukkan adanya multikolineritas adalah nilai Tolerance $\leq 0,10$ atau sama dengan nilai VIF $\geq 10$ (Ghozali, 2016). 
Statistik deskriptif memberikan gambaran atau deskripsi suatu data yang dilihat dari nilai rata-rata atau mean, standar deviasi, varian, maksimum, minimum, sam, range, kurtosis dan skewness (kemencengan distribusi) (Ghozali, 2016). Statistik deskriptif digunakan untuk menganalisis data dengan cara mendeskripsikan atau menggambarkan data yang telah terkumpul sebagaimana adanya tanpa bermaksud membuat kesimpulan yang berlaku untuk umum atau generalisasi (Sugiyono, 2017: 147).

Koefisisen determinasi (R2) digunakan untuk mengukur seberapa jauh kemampuan model dalam menerangkan variasi variabel dependen. Nilai koefisien determinasi antara nol dan satu. Semakin nilai R2 mendekati satu maka variabelvariabel independen memberikan hampir semua informasi yang dibutuhkan untuk memprediksi variasi variabel dependen (Ghozali, 2016). Nilai koefisien determinasi adalah antara nol dan satu. Nilai R2 yang kecil berarti kemampuan variabel-variabel independen dalam menjelaskan variabel dependen amat terbatas. Nilai yang mendekati satu berarti variabel-variabel independen memberikan hampir semua informasi yang dibutuhkan untuk memprediksi variasi variabel dependen.

Dalam penelitian ini teknik analisis data menggunakan analisis regresi linear berganda dengan menggunakan program SPSS. Analisis regresi berganda merupakan ekstensi dari model regresi dalam analisis bivariante yang umumnya digunakan untuk menguji pengaruh dua atau lebih variabel independen terhadap variabel dependen dengan skala pengukuran interval atau rasio dalam suatu linier (Indriantoro dan Supomo 1999).

Persamaan regresi linear berganda adalah :

$$
\begin{aligned}
& \mathrm{Y}=\alpha+\beta 1 \mathrm{X} 1+\beta 2 \mathrm{X} 2+\beta 3 \mathrm{X} 3+\mathrm{e} \\
& \text { Keterangan : } \\
& \mathrm{Y} 1=\text { Kepatuhan Wajib Pajak } \\
& \mathrm{A} 1=\text { Nilai konstanta } \\
& \beta 1-\beta 3=\text { Koefisien regresi dan estimator dari parameter } \\
& \mathrm{X} 1=\text { Pelaksanaan Self Assessment System } \\
& \mathrm{X} 2=\text { Kualitas Pelayanan } \\
& \mathrm{X} 3=\text { Pemeriksaan Pajak }
\end{aligned}
$$

Uji hipotesis (uji t) ini bertujuan untuk mengetahui seberapa jauh pengaruh satu variabel independen secara individual dalam menerangkan variasi variabel dependen (Ghozali, 2016). Kriteria penerimaan dan penolakan hipotesis adalah:

1. Jika $t$ hitung $>\mathrm{t}$ tabel, maka Ho diterima (ada pengaruh signifikan)

2. Jika thitung $<\mathrm{t}$ tabel, maka Ho ditolak (tidak ada pengaruh)

Berdasarkan dasar signifikansi, kriterianya adalah:

1. Jika signifikansi > 0,05 maka Ho ditolak

2. Jika signifikansi $<0,05$ maka Ho diterima 


\section{HASIL PENELITIAN}

Tabel 4. Hasil Uji Validitas

\begin{tabular}{llll} 
Item & rhitung & rtabel & Keterangan \\
\hline SA1 & 0.820 & 0.083 & Valid \\
SA2 & 0.823 & 0.083 & Valid \\
SA3 & 0.880 & 0.083 & Valid \\
SA4 & 0.870 & 0.083 & Valid \\
SA5 & 0.705 & 0.083 & Valid \\
KP1 & 0.748 & 0.083 & Valid \\
KP2 & 0.610 & 0.083 & Valid \\
KP3 & 0.779 & 0.083 & Valid \\
KP4 & 0.733 & 0.083 & Valid \\
KP5 & 0.819 & 0.083 & Valid \\
PP1 & 0.771 & 0.083 & Valid \\
PP2 & 0.846 & 0.083 & Valid \\
PP3 & 0.606 & 0.083 & Valid \\
KWP1 & 0.859 & 0.083 & Valid \\
KWP2 & 0.795 & 0.083 & Valid \\
KWP3 & 0.735 & 0.083 & Valid \\
KWP4 & 0.826 & 0.083 & Valid \\
& & & Sumber: Data primer yang diolah
\end{tabular}

Tabel. 4 menunjukkan self assessment, kualitas pelayanan, pemeriksaan pajak dan kepatuhan wajib pajak mempunyai kriteria valid untuk semua item pertanyaan dengan nilai $r$ hitung lebih besar dari $r$ tabel dan nilai positif maka butir pertanyaan atau indikator tersebut dinyatakan valid.

\section{Tabel 5. Hasil Uji Reabilitas}

\begin{tabular}{lclcc} 
Variabel & $\begin{array}{l}\text { Cronbach's } \\
\text { Alpha }\end{array}$ & $\begin{array}{l}\text { Cronbach's Alpha } \\
\text { Standardized Items }\end{array}$ & $\begin{array}{c}\text { Based } \\
\text { onN } \\
\text { Items }\end{array}$ \\
\hline Self Assessment & .874 & .878 & 5 \\
Kualitas Pelayanan & .778 & .795 & 5 \\
Pemeriksaan Pajak & .798 & .823 & 3 \\
Kepatuhan Wajib Pajak & .817 & .819 & 4
\end{tabular}

Sumber: Data primer yang diolah

Tabel 5 menunjukkan nilai cronbach's alpha atas semua variable $>0.70$, sehingga dapat disimpulkan bahwa pernyataan dalam kuesioner ini reliabel. 
Pada uji normalitas dengan menggunakan grafik normal plot, terlihat titiktitik menyebar disekitar garis diagonal serta penyebarannya mengikuti arah garis diagonal.

\section{Normal P-P Plot of Regression Standardized Residual}

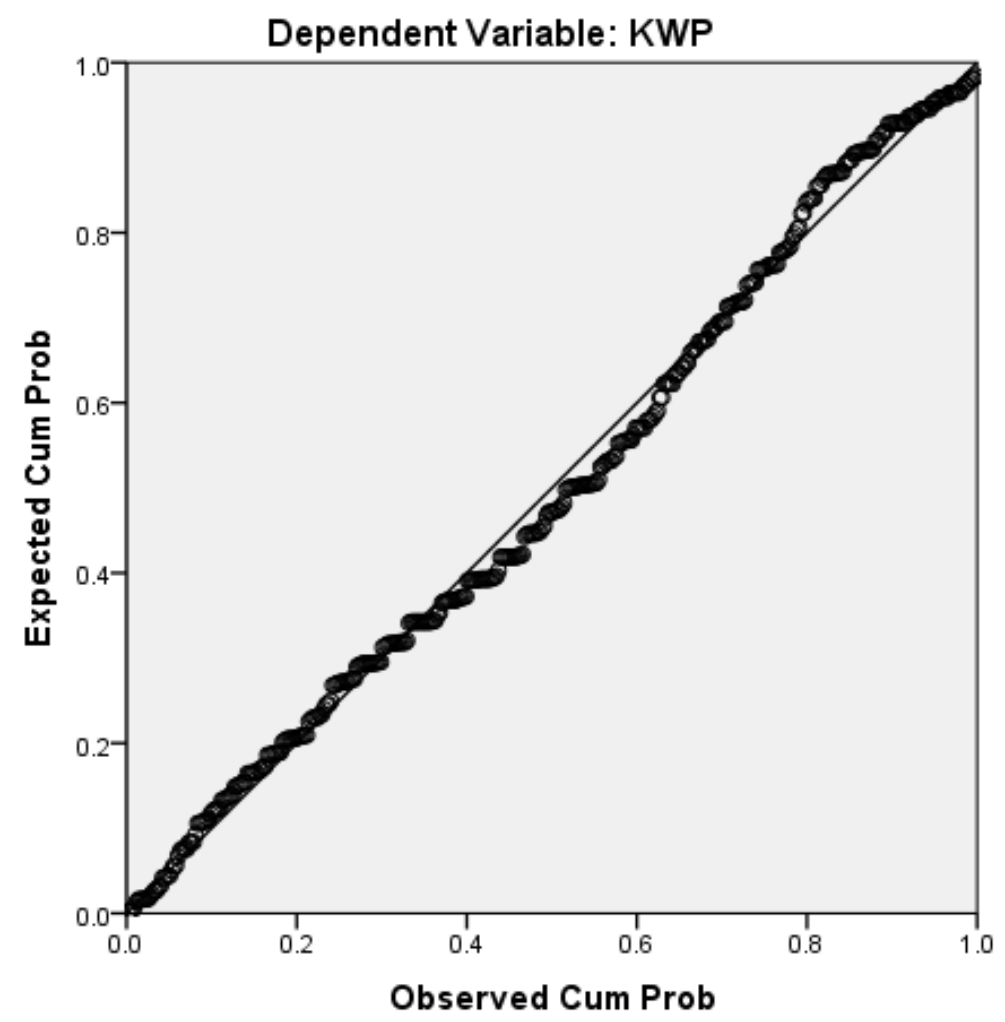

Sumber: Data primer yang diolah

Gambar 2. Normal probability plot

Tabel 6. Hasil Uji t Statistik

Coefficients $^{\mathrm{a}}$

\begin{tabular}{|c|c|c|c|c|c|c|}
\hline \multirow{2}{*}{\multicolumn{2}{|c|}{ Model }} & \multicolumn{2}{|c|}{$\begin{array}{l}\text { Unstandardized } \\
\text { Coefficients }\end{array}$} & \multirow{2}{*}{$\begin{array}{l}\text { Standardized } \\
\text { Coefficients } \\
\text { Beta }\end{array}$} & \multirow[b]{2}{*}{$\mathrm{t}$} & \multirow[b]{2}{*}{ Sig. } \\
\hline & & B & Std. Error & & & \\
\hline \multirow[t]{4}{*}{1} & (Constant) & 4.942 & 1.090 & & 4.533 & .000 \\
\hline & SA & .248 & .042 & .273 & 5.880 & .000 \\
\hline & $\mathrm{KP}$ & .120 & .035 & .156 & 3.403 & .001 \\
\hline & PP & .368 & .065 & .270 & 5.642 & .000 \\
\hline
\end{tabular}

a. Dependent Variable: KWP

Sumber: Data primer yang diolah

Dari tabel 6 terlihat bahwa thitungkoefisien self assessment sebagai variabel X1 terhadap Kepatuhan Wajib Pajak sebagai variabel Y menunjukkan 
$t_{\text {hitung }}$ sebesar 5.880, sedangkan $t_{\text {tabel }}$ bisa dihitung pada tabel $t$ test, dengan $(\alpha=$ $0.05)$, karena dilakukan hipotesis dua arah, ketika mencari $t_{\text {tabel }}$ nilai $\alpha$ dibagi 2 menjadi 0.025 dan $\mathrm{df}=388$ (didapat dari rumus $\mathrm{n}-2$ dimana $\mathrm{n}$ adalah jumlah data, $390-2=388)$. Didapat $t_{\text {tabel }}$ adalah 1.96. Karena memiliki nilai $p$-value 0.00 (0.00 $<0.05)$ sedangkan $t_{\text {hitung }}>t_{\text {tabel }}(5.88>1.96)$ maka hipotesis alternatif $\left(\mathrm{H}_{\mathrm{a}}\right)$ diterima dan hipotesis nol $\left(\mathrm{H}_{0}\right)$ ditolak, artinya self assessment berpengaruh positif terhadap kepatuhan wajib pajak.

Untuk kualitas pelayanan sebagai variabel X2 terhadap Kepatuhan Wajib Pajak sebagai variabel $Y$ menunjukkan $t_{\text {hitung }}$ sebesar 3.403, sedangkan $t_{\text {tabel }}$ bisa dihitung pada tabel t test, dengan $(\alpha=0.05)$, karena dilakukan hipotesis dua arah, ketika mencari $t_{\text {tabel }}$ nilai $\alpha$ dibagi 2 menjadi 0.025 dan $\mathrm{df}=388$ (didapat dari rumus n-2 dimana $n$ adalah jumlah data , 390-2 = 388). Didapat $t_{\text {tabel }}$ adalah 1.96.Karenamemiliki nilai $p$-value $0.01(0.01<0.05)$ sedangkan $t_{\text {hitung }}>t_{\text {tabel }}$ $(3.403>1.96)$ maka hipotesis alternatif $\left(\mathrm{H}_{\mathrm{a}}\right)$ diterima dan hipotesis nol $\left(\mathrm{H}_{0}\right)$ ditolak, artinya kualitas pelayanan berpengaruh positif terhadap kepatuhan wajib pajak.

Untuk pemeriksaan pajak sebagai variabel X3 terhadap Kepatuhan Wajib Pajak sebagai variabel $\mathrm{Y}$ menunjukkan $\mathrm{t}_{\text {hitung }}$ sebesar 5.642, sedangkan $\mathrm{t}_{\text {tabel }}$ bisa dihitung pada tabel t test, dengan $(\alpha=0.05)$, karena dilakukan hipotesis dua arah, ketika mencari $t_{\text {tabel }}$ nilai $\alpha$ dibagi 2 menjadi 0.025 dan $\mathrm{df}=388$ (didapat dari rumus n-2 dimana $\mathrm{n}$ adalah jumlah data , 390-2 = 388). Didapat $\mathrm{t}_{\text {tabel }}$ adalah 1.96.Karenamemiliki nilai p-value $0.00(0.00<0.05)$ sedangkan $t_{\text {hitung }}>t_{\text {tabel }}$ $(5.642>1.96)$ maka hipotesis alternatif $\left(\mathrm{H}_{\mathrm{a}}\right)$ diterima dan hipotesis nol $\left(\mathrm{H}_{0}\right)$ ditolak, artinya pemeriksaan pajak berpengaruh positif terhadap kepatuhan wajib pajak.

\section{SIMPULAN DAN SARAN}

\subsection{Simpulan}

Berdasarkan hasil analisis dan pembahasan tentang pengaruh pelaksanaan self assessment system, kualitas pelayanan dan pemeriksaan pajak terhadap kepatuhan wajib pajak studi pada wajib pajak orang pribadi yang terdaftar di KPP Pratama Kebayoran Baru Tiga. Responden dalam penelitian ini berjumlah 390 orang Wajib Pajak, maka dapat ditarik kesimpulan sebagai berikut :

1) Berdasarkan hasil uji parsial, menunjukkan bahwa variabel self assessment berpengaruh terhadap kepatuhan Wajib Pajak Orang Pribadi yang terdaftar di KPP Pratama Kebayoran Baru Tiga.

2) Untuk variabel kualitas pelayanan, berdasarkan uji parsial menunjukkan bahwa kualitas pelayanan berpengaruh terhadap kepatuhan Wajib Pajak Orang Pribadi yang terdaftar di KPP Pratama Kebayoran Baru Tiga.

3) Untuk variabel pemeriksaan pajak,berdasarkan uji parsial menunjukkan bahwa pemeriksaan pajak berpengaruh terhadap kepatuhan Wajib Pajak Orang Pribadi yang terdaftar di KPP Pratama Kebayoran Baru Tiga.

\subsection{Saran}


Berdasarkan hasil temuan, saran yang diajukan adalah sebagai berikut.

1) Untuk KPP Pratama Kebayoran Baru Tiga

Aparat pajak harus tetap meningkatkan kinerjanya kedepan khususnya kualitas pelayanan agar Wajib Pajak merasa nyaman, sehingga kepatuhan dalam hal membayar pajak dapat meningkat dan membantu peningkatan ekonomi dalam bidang perpajakan.

2) Untuk Peneliti Selanjutnya

Dalam penelitian ini hanya fokus pada tiga variabel yaitu self assessment system, kualitas pelayanan, dan pemeriksaan pajak. Peneliti selanjutnya bisa menambah variabel lain yang dapat mempengaruhi kepatuhan Wajib Pajak, serta memperluas wilayah sampel peneliti, sehingga hasilnya dapat digeneralisasikan untuk lingkup yang lebih luas.

\section{DAFTAR PUSTAKA}

Amanda, C.P., Rifa, D., \& Minovia, A. F. 2014, 'Pengaruh Kesadaran Wajib Pajak, Sanksi Pajak, Pelayanan Fiskus dan Pemeriksaan Pajak Terhadap Kepatuhan Wajib Pajak"

Andyastuti, L., Topowijono., \& Husaini, A. 2013, "Pengaruh Penyuluhan, Pelayanan, Pemeriksaan, Dan Sanksi Terhadap Kepatuhan Penyampaian Surat Pemberitahuan Tahunan Orang Pribadi (Studi Pada KPP PRatama Malang Utara)

Anjarini, K., Prasetyo, H. B., \& Irani, L. D. 2012, "Analisis Pelaksanaan Pemeriksaan Pajak Dalam Meningkatkan Kepatuhan Wajib Pajak Orang Pribadi”, Jurnal Akuntansi Perpajakan.

Budi, C. 2014, Buka Rahasia Bank Untuk Pajak. Diakses 19 Maret 2018 http://www.investor.co.id/home/bukarahasia-bank-untuk-pajak/79026

Ester, K. G. Nangoi, G. B., \& Alexander, S. W. 2017, 'Pengaruh Kualitas Pelayanan Pajak Dan Pengetahuan Wajib Pajak TerhadapKepatuhan Wajib Pajak Orang Pribadi', Jurnal Riset Akutansi Going Concern, Vol. 12, No. 2, hal. 523-530.

Ghozali, I 2016, Aplikasi Analisis Multivariate Dengan Program IBM SPSS 23 Edisi8, Badan Penerbit Universitas Diponegoro, Semarang.

Jotopurnomo, C., \& Mangoting, Y 2013, 'Pengaruh Kesadaran Wajib Pajak, Kualitas Pelayanan Fiskus, Sanksi Perpajakan, Lingkungan Wajib Pajak BeradaTerhadap Kepatuhan Wajib Pajak Orang Pribadi', Tax AndAccounting Review, Vol. 1, No. 1, hal. 50-54.

Kementrian Keuangan 2018, Informasi APBN 2018. Diakses 19 Maret 2018 https://www.kemenkeu.go.id/media/6886/informasi-apbn-2018.pdf

Kementrian Keuangan 2016, Informasi APBN 2016. Diakses 19 Maret 2018 www.kemenkeu.go.id/sites/default/files/bibfinal.pdf 
Kementrian Keuangan 2017, Informasi APBN 2017. Diakses 19 Maret 2018 https://www.anggaran.depkeu.go.id/content/publikasi/2016\%20BIB\%2020 17.pdf

Isa, K., \& Pope, J. 2010, 'Corporate Tax Audits: Evidence From Malaysia', Global Review of Accounting and Finance, Vol. 2, No. 1, pp 42-56.

Lasmaya, M. S., \& Nur, N. F. 2017, 'Pengaruh Self Assessment System Terhadap KepatuhanWajib Pajak, Jurnal Computech \& Bisnis, Vol. 11, No. 2, hal. 69-78.

Parasuraman, A., Zeithami, V. A., \& Berry, L. L. 1988, 'SERVQUAL: AMultiple-Item Scale for Measuring Consumer Perceptions of Service Quality', Journal of Retailing, Vol. 64, No. 1, pp. 14.

Manuputty, I. G., \& Swanto, S. 2016, 'Pengaruh Pengetahuan Perpajakan dan Penerapan Self Assessment System Terhadap Kesadaran Wajib Pajak Serta Dampaknya Terhadap Kepatuhan Wajib Pajak',Media Akuntansi Perpajakan, Vol. 1, No. 2, hal. 44-58.

Mardiana, G. A., Wahyuni, A. M., \& Herawati, N. T, 2016, 'Pengaruh Self Assessment, Tingkat Pengetahuan Perpajakan, Tingkat Pendapatan, Sanksi Pajak, Persepsi Wajib Pajak Tentang Sistem Perpajakan, Dan KualitasPelayanan terhadap Kepatuhan Membayar Pajak', Jurnal Akuntansi, Vol. 6, No. 4.

Mardiasmo, 2016, Perpajakan, CV Andi Offset, Yogyakarta.

Nurhayati, N., Halimatusadiah, E., \& Diamonalisa 2015, 'Influence of Tax Officer Service Quality and Knowledge of Tax on Individual Taxpayer Compliance in Tax Office', International Journal of Applied Research, Vol. 1, No. 8, pp. 805-809.

Peraturan Menteri Keuangan No 74/PMK.03/2012 tentang Tata Cara Penetapan Dan Pencabutan Penetapan Wajib Pajak Dengan Kriteria Tertentu Dalam Rangka Pengembalian Pendahuluan Kelebihan Pembayaran Pajak

Peraturan Menteri Keuangan No PER-176/PJ./2006 tentang Perubahan Atas Peraturan DJP No Per-123/PJ./2006 tentang Petunjuk Pelaksanaan Pemeriksaan Lapangan

Peraturan Menteri Keuangan No 213/PJ./2003 tentang Perubahan Atas Keputusan DJP No KEP-550/PJ./2000 tentang Tata Cara Penetapan Wajib Pajak Yang Memenuhi Kriteria Tertentu Dan Penyelesaian Permohonan Pengembalian Kelebihan Pembayaran Pajak Dalam Rangka Pengembalian Pendahuluan Kelebihan Pembayaran Pajak

Rahayu, M. P. 2016, 'Pengaruh Kesadaran Perpajakan dan Pemeriksaan Terhadap Kepatuhan Wajib Pajak Orang Pribadi'.

Rahayu, S. K. 2010, Perpajakan Indonesia, Konsep Dan Aspek Formal, Graha Ilmu, Yogjakarta. 
Rahayu, S. K. 2017, Perpajakan, Konsep Dan Aspek Formal „Rekayasa Sains, Bandung.

Setyono, A. D. 2017, 'Pengaruh Self Assessment System Terhadap Kepatuhan Wajib Pajak Orang Pribadi'.

Suandi, E 2011, Hukum Pajak, Edisi 5. Salemba Empat, Jakarta

Sugiyono 2017, Metode Penelitian Kuantitatif, Kualitatif dan R\&D. Alfabeta, Bandung.

Sumpena, D 2014, 'Pengaruh Pelaksanaan Self Assessment System dan Pengetahuan Pajak terhadap Kepatuhan Wajib Pajak'.

Syahril, F 2013, 'Pengaruh Tingkat Pemahaman Wajib Pajak dan Kualitas Pelayanan Fiskus terhadap Tingkat Kepatuhan Wajib Pajak'.

Tjiptono, F 2015, Service, Quality Dan Satisfaction, Edisi 4. CV Andi Offset, Yogyakarta.

Waluyo 2008, Perpajakan Indonesia. Edisi 11. Salemba Empat, Jakarta. 